\title{
High-density chitosan reduces the severity of bacterial spot and activates the defense mechanisms of tomato plants
}

\author{
Nathalie Garbelotti de Jail, Caroline Luiz, Argus Cezar da Rocha Neto \& Robson Marcelo Di Piero \\ Centro de Ciências Agrárias, Universidade Federal de Santa Catarina, Rodovia Admar Gonzaga, 1346, Bairro Itacorubi, \\ 88034-001, Florianópolis, SC, Brazil
}

Author for correspondence: Robson Marcelo Di Piero, e-mail: robson.piero@ufsc.br

\begin{abstract}
Bacterial spot, caused by Xanthomonas gardneri, is a disease of great importance for tomato crops, especially due to yield reduction. The objective of this study was to evaluate the effectiveness of low - and high-density chitosan for the control of bacterial spot and whether such control was due to activation of defense mechanisms in tomato. Tomato plants were treated with high-density (HD; 0.8 $\mathrm{g} / \mathrm{cm}^{3}$ ) or low-density chitosan $\left(\mathrm{LD} ; 0.4 \mathrm{~g} / \mathrm{cm}^{3}\right.$ ) at concentrations ranging from 0.0 to $3.0 \mathrm{mg} / \mathrm{mL}$, and then inoculated with a bacterial suspension three days later. The effect of varying intervals (7, 5, 3 and 1 day) between the application of HD chitosan ( $3 \mathrm{mg} / \mathrm{mL})$ and the inoculation of the pathogen was also assessed. The effect of chitosan on the in vitro growth of $X$. gardneri and the activities of peroxidases and polyphenol oxidases in leaves were also determined. HD chitosan $(3.0 \mathrm{mg} / \mathrm{mL})$ was able to greatly reduce disease severity by up to $85 \%$ compared to the control. The application of HD-chitosan at five days before inoculation showed larger reduction in disease severity and high level of peroxidase activity. The in vitro growth of $X$. gardneri was not affected by the treatment with chitosan, thus suggesting that the disease was controlled due to mechanisms related to induced resistance.
\end{abstract}

Key words: Xanthomonas gardneri, alternative control, induction of resistance, peroxidases, poliphenol oxidases.

\section{INTRODUCTION}

Native to the Andes coast, the tomato plant (Solanum lycopersicum L.) is the second most economically important vegetable crop in Brazil. Because tomato plants are highly adaptable to different weather conditions, they are grown in several regions of the world. Currently, Brazil is one of the world's largest tomato producers and the state of Santa Catarina is among the largest producers in the country. The town of Caçador has the largest planted area in Santa Catarina, with a yield of $85,000 \mathrm{~kg}$ per hectare (IBGE, 2012).

Even though tomato plants are adapted to the soil and climate conditions of the producing regions, their development and yield may be affected by the occurrence of plant pathogens. As a biotic factor, diseases caused by phytobacteria play a crucial role in reducing yield. One example is bacterial spot (Xanthomonas gardneri), which can affect the yield and quality of tomatoes.

For control of tomato bacterial spot, cupric products are mostly used. However, they have not controlled the disease effectively and cause adverse effects on plant development and the environment, depending on when and how they are applied (Usataya et al., 1993; Sukul \& Spiteller, 2000). Awareness of pesticide related problems has increased significantly, and that is partly due to the perception of consumers, who are much more concerned about their health and well-being. Currently, the quality factor is not only associated with the appearance of the product, but also with the issue of health (Janisiewicz, 1996). Thus, researchers are increasingly challenged to seek new alternatives to control these pathogens, and the induction of resistance through natural substances is a great option for solving this problem.

In this case, induction of resistance is established by exposing the plant to molecules capable of eliciting and promoting the activation of defense mechanisms (Cluzet et al., 2004). Thus, the use of natural or biodegradable compounds, such as polysaccharides, may be a viable alternative especially because they do not contaminate the environment and do not leave toxic residues that are harmful to man and animals.

Chitosan, abiopolymerderived from the deacetylation of chitin, is one of the polysaccharides that have been effective in the control of some pathogens that cause diseases in crops. Some of the properties of chitosan are the ability to directly affect the growth of many microorganisms and to reduce the severity of plant diseases. Sivakumar et al. (2005) studied the influence of chitosan (1\%) and the combination of this polymer with ammonium carbonate $(3 \%)$ or sodium bicarbonate $(2 \%)$ in reducing the incidence of anthracnose (Colletotrichum gloeosporioides) in papaya (Carica papaya). The authors observed that chitosan alone or combined decreased significantly the disease severity in naturally or artificially inoculated fruits.

Chitosan, in addition to acting directly on pathogens, can activate defense responses of plant tissues and, as a result, induce the synthesis of lignin or callose, the production of 
phytoalexins and hydrogen peroxide, the accumulation of chitinases and peroxidases, etc (Berger et al., 2011). This polymer is able to change the activity of plant enzymes, reduce disease and improve the storage life of fruit. Reuck et al. (2009) reported that chitosan $(1.0 \mathrm{~g} / \mathrm{L})$ was effective in preventing deterioration and browning during storage litchi. The authors verified that the chitosan reduced the activity of polyphenol oxidase (PPO) and peroxidase (POD), maintaining the integrity of the membrane and preventing the decline of anthocyanins and the color of the pericarp of the fruit.

Currently, chitosan is obtained from crab and shrimp shells as a waste produced by fishing industry activity. Using this polysaccharide in the control of pathogens is interesting and advantageous. It is able to improve methods of plant disease control and, at the same time, it provides a better destination for such waste.

The present study aimed to evaluate the efficiency of high and low-density chitosan in the control of bacterial spot in tomato plants as well as verify the influence of chitosan on the activity of enzymes responsible for plant defense.

\section{MATERIAL AND METHODS}

\section{Plant pathogen and chitosans}

The isolate of Xanthomonas sp. was obtained from symptomatic tomato plants of the cultivar Carmen, grown in Águas Mornas (state of Santa Catarina), and kindly provided by Sakata Seed Sudamerica Ltda. The bacterium was identified by Embrapa Hortaliças (Brasília, DF, Brazil) and it was confirmed by BOX-PCR that the strain was Xanthomonas gardneri, Group D (Coqueiro \& Di Piero, 2011). Furthermore, the genome of Xanthomonas was compared with that of the isolates of species associated with tomato bacterial spot: IBSBF 2363 (X. euvesicatoria), IBSBF 2364 (X. vesicatoria), IBSBF 2370 (X. perforans) and IBSBF 2373 ( $X$. gardneri), from the collection of phytobacteria of the Instituto Biológico, Campinas, Brazil (Coqueiro \& Di Piero, 2011). The bacterium was kept in a phosphate buffer $\left(7.4 \mathrm{mM} \mathrm{KH}_{2} \mathrm{PO}_{4}, 8.6 \mathrm{mM} \mathrm{K}_{2} \mathrm{HPO}_{4}\right)$ at $25^{\circ} \mathrm{C}$.

For the assays, the bacterium was transferred to Petri dishes containing Nutrient agar [composition $(\mathrm{g} / \mathrm{L})$ : meat peptone 5.0; meat extract 3.0, agar 12.0)] (Merck) and incubated in the dark for two days at room temperature $\left(25^{\circ} \mathrm{C}\right)$. The bacterial suspension was obtained by adding distilled water on the previously colonized dishes. At the end, the suspension concentration was adjusted to 0.6 absorbance units at $600 \mathrm{~nm}$ with the aid of a spectrophotometer (Luiz et al. 2012).

Two types of commercial chitosan extracted from the shell of crustaceans, one with high density $\left(0.8 \mathrm{~g} / \mathrm{cm}^{3}\right)$ and the other with low density $\left(0.4 \mathrm{~g} / \mathrm{cm}^{3}\right)$, were provided by Prof. Dr. Luiz Henrique Beirão from the Dep. de Ciência e Tecnologia de Alimentos, Universidade Federal de Santa Catarina. The suspensions of high density (HD) and low density (LD) chitosans were prepared by dissolving them in $0.05 \mathrm{~N} \mathrm{HCl}$ with constant stirring and $\mathrm{pH}$ adjustment to 5.6 with $2 \mathrm{M} \mathrm{NaOH}$.

\section{Conductimetric analysis to ascertain the degree of chitosan deacetylation}

For conductimetric analysis of HD and LD chitosan, $200 \mathrm{mg}$ of each sample was diluted into $40 \mathrm{~mL}$ of $\mathrm{HCl}$ $(54 \mathrm{mM})$ with magnetic stirring at $100 \mathrm{rpm}$ for a period of $3 \mathrm{~h}$ at a temperature of $25^{\circ} \mathrm{C}$. After the stir period, one conductimetric electrode was added to the solution. Titration was performed by adding $0.5 \mathrm{~mL}$ of $\mathrm{NaOH}(165 \mathrm{mM})$ every $20 \mathrm{sec}$ for $13 \mathrm{~min}$ (adapted from Alvarenga et al., 2010). Through two inflection points that occur during titration, it was possible to estimate the degree of deacetylation (DD) of the chitosans studied. The DD of the samples was calculated using the following equation:

$$
\% \mathrm{DD}=\frac{[\mathrm{NaOH}](\mathrm{V} 2-\mathrm{V} 1) 161}{\mathrm{~m}}
$$

where: $[\mathrm{NaOH}]$ is the concentration of the $\mathrm{NaOH}$ solution (mol/L); $V 1$ and $V 2$ are the volumes of $\mathrm{NaOH}$ $(\mathrm{mL})$ used up to the initial and final inflection points during titration; 161 is the molar mass of the glucosamine monomer $\left(\mathrm{C}_{6} \mathrm{H}_{11} 0_{4} \mathrm{~N}\right)$; and $m$ is the mass of chitosan (in $\mathrm{mg})$.

\section{Effect of chitosans on the severity of bacterial spot}

All the experiments were conducted in a greenhouse belonging to the Lab. de Fitopatologia of the Universidade Federal de Santa Catarina. Tomato seeds (cv. Santa Cruz Kada) susceptible to Xanthomonas spp. were sown in 128 cell trays with Plantmax HA substrate. After two weeks of sowing, the seedlings were transplanted to $2 \mathrm{~L}$ plastic pots with soil and Plantmax HA substrate (5:1). The study used a completely randomized design with 6 replicates per treatment. Each pot with two plants was considered as an experimental unit.

Initially, the effect of HD orLDchitosan on the severity of tomato bacterial spot was assessed at concentrations of 0 , $0.75,1.5$ and $3.0 \mathrm{mg} / \mathrm{mL}$. Plants at the five-leaf stage were sprayed with $8 \mathrm{~mL}$ of the chitosan suspension. Plants treated with distilled water or acibenzolar-S-methyl (ASM) at 25 $\mu \mathrm{g} / \mathrm{mL}$, a resistance inducer registered for tomato plants, were used as negative and positive control respectively. Four days after the treatments were applied, the plants were inoculated with the suspension of $X$. gardneri at a concentration of 0.6 absorbance units at $600 \mathrm{~nm}$. After this stage, a moist chamber was used for $48 \mathrm{~h}$. After 15 days of inoculation, the disease was assessed by estimating the severity of bacterial spot (\% of necrotic leaf area) of two leaves of each plant with the aid of a diagrammatic scale. Five levels of necrotic leaf area $(1 \%, 5 \%, 15 \%, 25 \%$ and $50 \%$ ) compose the representative diagrams of the scale (Mello et al., 1997). 
Then, in another experiment, conducted in the same manner as described above, it was evaluated how the time interval between the application of chitosan and bacterial inoculation influenced the severity of the disease. In this case, the plants were sprayed with HD chitosan $\left(0.8 \mathrm{~g} / \mathrm{cm}^{3}\right)$ at a concentration of $3 \mathrm{mg} / \mathrm{mL}$, and after a period of 7, 5, 3 or 1 day(s), they were inoculated with the bacterium $\left(\mathrm{A}_{600 \mathrm{~mm}}\right.$ $=0.6$ ). Six replicates were made for each treatment and the disease was assessed 15 days after inoculation.

\section{Antimicrobial effect of different chitosans on Xanthomonas gardneri}

In this assay, HD and LD chitosans were added at a final concentration of $3 \mathrm{mg} / \mathrm{mL}$ in the culture medium (Nutrient agar). The chitosan suspensions, as well as the culture medium, were autoclaved for $20 \mathrm{~min}$ at $120^{\circ} \mathrm{C}$ before they were placed in the Petri dishes. After solidification of the medium with the added polysaccharide, aliquots of $100 \mu \mathrm{L}$ of the bacterial suspension with $\mathrm{A}_{600 \mathrm{~nm}}=0.6$ were transferred and spread on the surface of the medium with the aid of a Drigalski spatula. The Petri dishes were incubated at $25^{\circ} \mathrm{C}$ in the dark for $48 \mathrm{~h}$ and the evaluation of the bacterial growth was performed by obtaining a bacterial suspension in distilled water, and absorbance was read in a spectrophotometer at $600 \mathrm{~nm}$. Five replicates were made for each treatment, and each Petri dish was considered an experimental unit.

\section{Determining the activity of peroxidases and polyphenol oxydases}

Tomato plants at the five-leaf stage were sprayed with a suspension of $\mathrm{HD}$ chitosan at $3 \mathrm{mg} / \mathrm{mL}$ at different time intervals between treatment and inoculation with $X$. gardneri (7, 5, 3 and 1 days). As positive and negative controls, $0.05 \mathrm{~N} \mathrm{HCl}$ (pH 5.6) and ASM at $25 \mu \mathrm{g} / \mathrm{mL}$ were used, respectively. For each treatment, six replicates were made in a completely randomized design. The samples (five leaflets of the second leaf) were collected immediately before the inoculation (non-inoculated plants) and $48 \mathrm{~h}$ after (inoculated plants), and they were stored in a freezer and kept at $-80^{\circ} \mathrm{C}$ until time of maceration.

For protein extraction, samples were macerated in liquid nitrogen and homogenized in $1.5 \mathrm{~mL}$ of $100 \mathrm{mM}$ phosphate buffer ( $\mathrm{pH}$ 7.0). Then, they were centrifuged at $20,000 \mathrm{~g}$ for $30 \mathrm{~min}$ at $4^{\circ} \mathrm{C}$, recovering the supernatant, which is the protein extract.

Peroxidase activity was determined by direct spectrophotometry by measuring the conversion of guaiacol into tetraguaiacol at $470 \mathrm{~nm}$. The reaction was carried out with $20 \mu \mathrm{L}$ of protein extract mixed with $2.98 \mathrm{~mL}$ of a solution containing $250 \mu \mathrm{L}$ of guaiacol and $306 \mu \mathrm{L}$ of hydrogen peroxide in $100 \mathrm{~mL}$ of $50 \mathrm{mM}$ phosphate buffer (pH 6.0). The reaction was conducted at $30^{\circ} \mathrm{C}$ for $4 \mathrm{~min}$ and absorbance values were recorded every $30 \mathrm{sec}$ after the first minute of the reaction (Hammershmidt et al., 1982). Peroxidase activity was expressed as absorbance units per min per $\mathrm{mg}$ of protein.
Polyphenol oxidase activity was determined by measuring the conversion of catechol into quinone. The substrate was composed of $60 \mathrm{mM}$ catechol dissolved in $100 \mathrm{mM}(\mathrm{pH}$ 6.0) sodium phosphate buffer. For the reaction, which occurred at $40^{\circ} \mathrm{C}, 2.85 \mathrm{~mL}$ of the substrate were dissolved in $15 \mu \mathrm{L}$ of the protein extract obtained. Readings were taken every $3 \mathrm{sec}$ in a spectrophotometer at $420 \mathrm{~nm}$ for $1 \mathrm{~min}$. Finally, the activity was expressed as absorbance units per min per mg of protein (Duangmal \& Apentem, 1999).

\section{Total proteins}

Soluble proteins in the extracts were quantified by the method of Bradford (1976), with some adaptations. Thus, $5 \mathrm{~mL}$ of the reagent Coomassie Brilliant Blue was added to $10 \mu \mathrm{L}$ of the protein extract and $90 \mu \mathrm{L}$ of 100 $\mathrm{mM}$ extraction phosphate buffer ( $\mathrm{pH}$ 7.0). After 5 min of reaction, absorbance readings for the solutions were taken in a spectrophotometer at $595 \mathrm{~nm}$. Absorbance data of the extracts were compared with readings of bovine serum albumin (BSA) solutions at concentrations from 10 to 50 $\mu \mathrm{g} / \mathrm{mL}$ and converted into soluble protein concentration.

\section{Statistical analysis}

Analysis of variance (one-way or factorial ANOVA) and Tukey's test (multiple comparisons) were performed to the means of the variables.

\section{RESULTS AND DISCUSSION}

The chitosan molecule has different degrees of acetylation calculated from the average fraction of units of 2-acetamido-2-deoxy-D-glucopyranose present in the polymer chain (Roberts, 1992). The change in the distribution of these units and their deacetylation, that is, their conversion into 2-amino-2-deoxy-D-glucopyranose units, can lead to the rearrangement of the internal structure of the molecule, generating new configurations and consequently forming chitosans of different densities. Conductimetric analyses revealed that the degree of deacetylation of the low and high-density chitosans used in this study is $76 \%$ and $63 \%$, respectively (Figure 1).

In addition to changing the density of the polysaccharide, the degree of chitosan deacetylation can affect the biological activity of the molecule. According to Falcón et al. (2008), the lower the degree of chitosan deacetylation, the greater its ability to activate plant defense mechanisms, such as the activity of peroxidases and phenylalanine-ammonia lyase. This helps explain the higher efficiency of high-density chitosan, with lower degree of deacetylation, for the control of tomato bacterial spot verified in the present study.

In the present study, tomato plants treated with LD chitosan $\left(0.4 \mathrm{~g} / \mathrm{cm}^{3}\right)$ at concentrations of $0.75,1.5,3.0$ $\mathrm{mg} / \mathrm{mL}$, and inoculated with $X$. gardneri ( 0.6 absorbance units at $600 \mathrm{~nm}$ ), exhibited no significant reduction in the 
High-density chitosan reduces the severity of bacterial spot and activates the defense mechanisms...

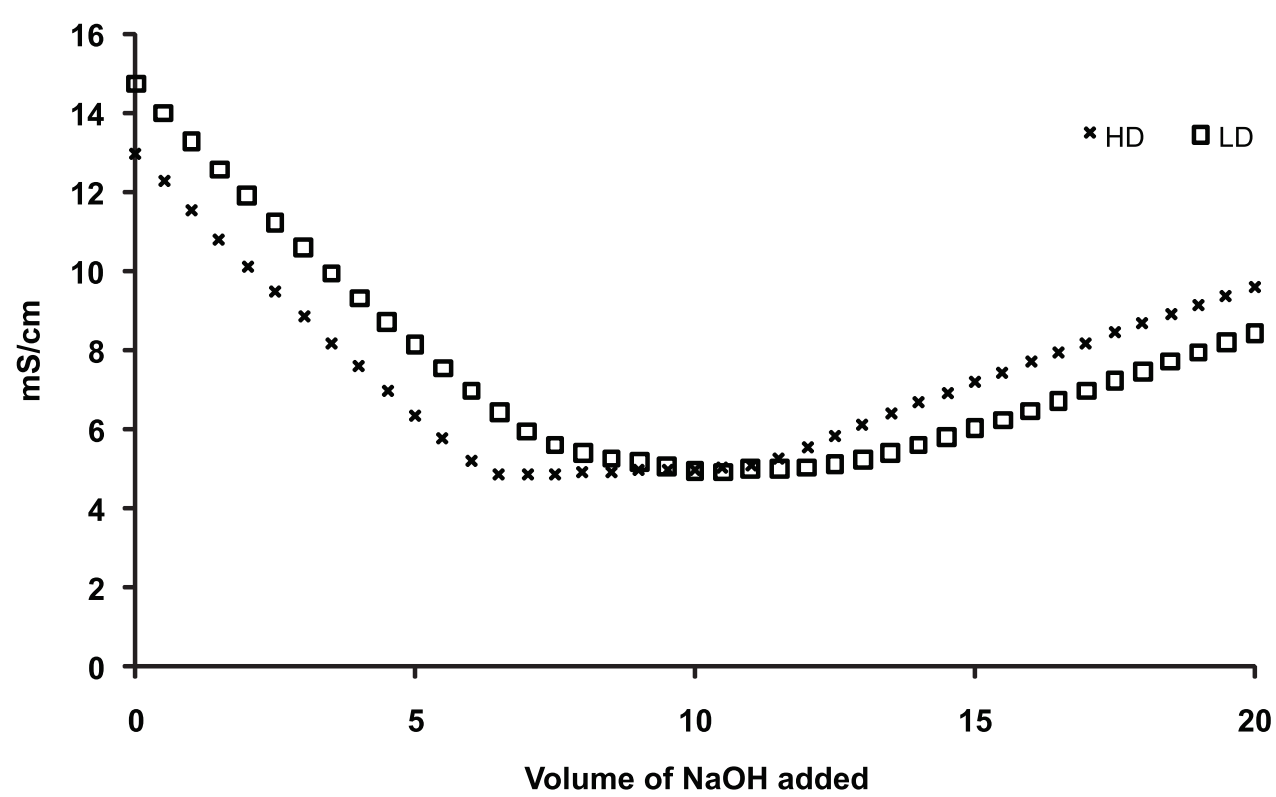

FIGURE 1 - Conductimetric titration for determining the degree of deacetylation of samples of low density (LD) and high density (HD) chitosan. severity of bacterial spot as compared to tomato plants treated with distilled water (negative control). However, HD chitosan $\left(0.8 \mathrm{~g} / \mathrm{cm}^{3}\right)$ significantly decreased severity at all tested rates, reducing up to $60 \%$ of the symptoms of the disease (Figure 2). This indicates that the physicochemical properties of chitosan may influence its potential for pathogen control. The commercial resistance inducer ASM reduced the severity of bacterial spot by $90 \%$. This result did not differ statistically of those reached with the HD chitosan at $3 \mathrm{mg} / \mathrm{mL}$ (Figure 2).

With respect to the effect of the time interval between treatment and inoculation, it was observed that at all tested time intervals (1, 3, 5 and 7 days), HD chitosan at a concentration of $3 \mathrm{mg} / \mathrm{mL}$ was able to control the disease, reducing severity by $77 \%$ on average compared with the control group. Among the plants treated with chitosan, those receiving the polysaccharide five days before inoculation showed the lowest severity (Figure 3). Similar results were found in the pathosystem bean-Colletotrichum lindemuthianum, where plants treated with chitosan four days before inoculation exhibited lower anthracnose severity compared to those treated in an interval of just one day (Di Piero \& Garda, 2008).

Several studies have been conducted in order to improve the effectiveness of chitosan in the control of plant diseases. Tan et al. (2013) and Chung et al. (2011), for example, tested different degrees of deacetylation, molecular weights, densities and quartenized derivatives of chitosan in order to verify its antimicrobial property. In these studies, it was observed that the higher the degree of deacetylation, the greater the antifungal activity of chitosan on Aspergillus flavus, Botrytis cinerea and Colletotrichum lagenarium. In contrast, the mode of antibacterial action is a more complex process due to differences in cell surface between Gram positive and Gram negative bacteria. However, even though there are differences, the bacteria seem to be generally less sensitive to the antimicrobial property of chitosan than fungi (Kong et al., 2010), which is in line with the results found in this study.

When evaluating the influence of HD and LD chitosan on the in vitro growth of $X$. gardneri, there was not a direct effect of the polysaccharide on the causal agent of bacterial spot, even in a concentration of $3 \mathrm{mg} / \mathrm{mL}$ (Figure 4). The degrees of deacetylation of the evaluated chitosans, 63 and $76 \%$, may not have been high enough to provide a significant antimicrobial activity, because it is speculated that this activity is dependent on the amount of positive charges on the chitosan molecule, which is directly proportional to the degree of deacetylation of the molecule. Therefore, it is suggested that the control of the disease by HD chitosan can be associated with other modes of action, such as the activation of latent defense mechanisms of the plant, which can be confirmed by evaluating the activity of certain enzymes responsible for plant defense.

Among these enzymes, peroxidases are particularly relevant. They are directly associated with the deposition of lignin in plant cell walls (van Loon \& van Strien, 1999), and they are involved in the oxidation of phenols and the production of compounds that are toxic to pathogens (Mandal et al., 2009). In the assays of the present study, a substantial increase was observed in the activity of this enzyme in plants treated with HD chitosan $(3.0 \mathrm{mg} / \mathrm{mL})$ compared with plants treated with distilled water (Figure 5).

Both non-inoculated and inoculated plants were elicited by the polysaccharide under study. In the first case, there was an average increase of approximately twice in the peroxidase activity compared with the control group (Figure 


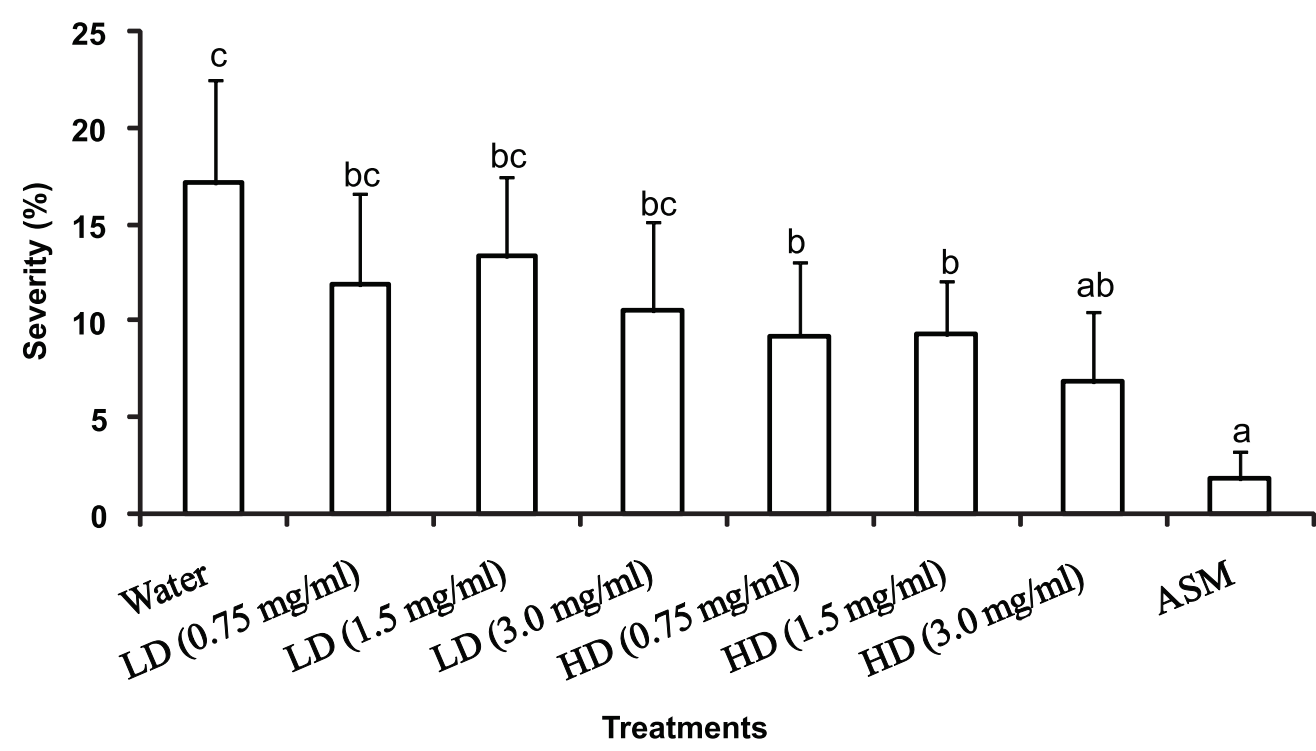

FIGURE 2 - Effect of low density (LD) and high density (HD) chitosan on the severity of tomato bacterial spot ( $X$. gardneri). Bars with the same letters are not statistically different from one another according to Tukey's test $(0.05 \%)$. ASM $=$ acibenzolarS-methyl $(25 \mu \mathrm{g} / \mathrm{mL})$.

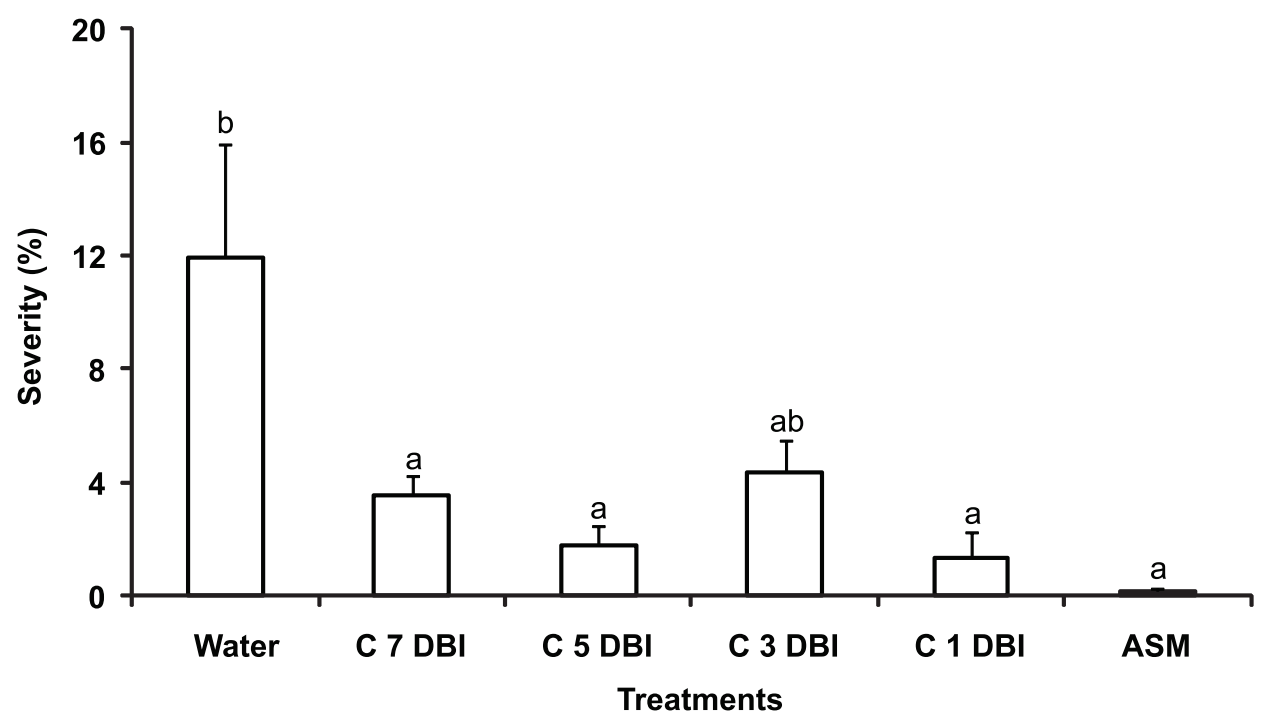

FIGURE 3 - Effect of high density chitosan (C) at $3 \mathrm{mg} /$ $\mathrm{mL}$, applied in tomato plants at different time intervals prior to inoculation, on the severity of bacterial spot (X. gardneri). Plants treated with distilled water and ASM $(25 \mu \mathrm{g} / \mathrm{mL})$, seven days before inoculation, were used as negative and positive controls, respectively. DBI: days before inoculation. Bars with the same letters are not statistically different from one another according to Tukey's test at $5 \%$ significance.

FIGURE 4 - Effect of low density (LD) and high density (HD) chitosan on the in vitro growth of $X$. gardneri. Bars with the same letter do not differ statistically from one another according to the Tukey's test at $5 \%$ significance. 


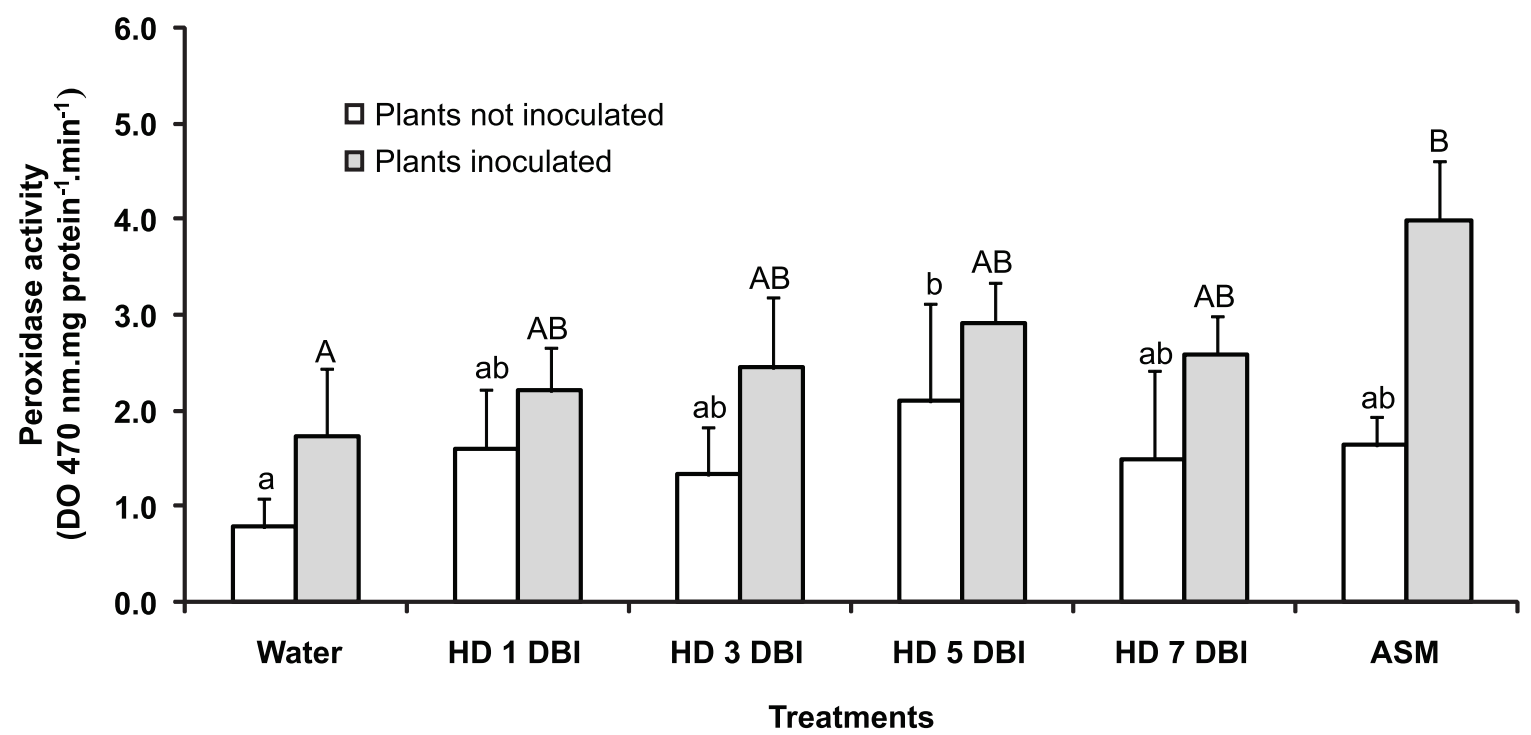

FIGURE 5 - Peroxidase activity in tomato leaves treated with high density (HD) chitosan at $3.0 \mathrm{mg} / \mathrm{mL}$, inoculated or not with Xanthomonas gardneri. Plants treated with distilled water and ASM $(25 \mu \mathrm{g} / \mathrm{mL})$ served as negative and positive controls, respectively. HD $1 \mathrm{DBI}$, for example, means plants treated with HD chitosan at 1 day before inoculation. The leaf samples were collected immediately before inoculation (non-inoculated plants) and $48 \mathrm{~h}$ after (inoculated plants) to quantify peroxidase activity. Bars with the same letters are not statistically different from one another according to Tukey's test at $5 \%$.

5). In tomato plants treated with chitosan five days before inoculation, a higher peak of peroxidase activity was found, coinciding with the lowest disease severity observed at this time interval (Figure 3). This reinforces the involvement of these enzymes in the control of bacterial spot.

In many cases, when the elicitor causes overexpression of enzymes, it shows no significant increase in enzyme activity after the inoculation of pathogens, such as occurred in tomato plants treated with HD chitosan and subsequently inoculated with $X$. gardneri. In the present study, there was an average increase of $31 \%$ of peroxidase activity in treated and inoculated plants compared to the inoculated control group (Figure 5).

It was observed that the non-inoculated plants treated with ASM showed no increase in peroxidase activity compared with those treated with water (Figure 5). However, peroxidase activity was only stimulated when they were exposed to bacteria, that is, the increased activity of this enzyme only occurred when the plants were challenged, thus showing the priming effect after application of ASM. Normally, ASM is expected to promote this induction, as other studies have shown that this substance can put the plant in a state of alert and activate its mechanisms effectively after the attack of a pathogen (Boava et al., 2010).

In addition to peroxidases, there are other enzymes responsible for the defense of plants against certain pathogens, such as polyphenol oxidases. These proteins are stored in thylakoids within chloroplasts, separated from the phenolic compounds which also are stored in the vacuoles.
When cell disruption caused by microorganisms takes place, polyphenol oxidases are released and start the process of oxidation of phenolic compounds to produce quinones, considered to be antimicrobial molecules. Therefore, it can be stated that these enzymes play an important role in the induction of plant resistance (Vaughn \& Duke, 1988).

Although polyphenol oxidases play an important role in plant defense against pathogenic microorganisms, the activity of these enzymes, in this assay, tended to decline in the plants treated with HD chitosan $(3.0 \mathrm{mg} / \mathrm{mL})$, whether or not inoculated with $X$. gardneri (Figure 6).

One hypothesis for this result may be associated with the fact that HD chitosan applied to tomato plants is eliciting the production of other substances capable of suppressing the activity of this enzyme. In other studies, specifically with stems of chrysanthemum and rose, it was found that the activity of both polyphenol oxidases and peroxidases can be interrupted by application of some compounds, for example phenylhydrazine, hydroquinone, nitrophenol, sodium metabisulfite and tropolone (Loubaud \& van Doorn, 2004; van Doorn \& Vaslier, 2002).

Unlike the chitosan with low molecular weight, which was effective in controlling tomato bacterial spot only at intervals shorter than three days and showed high antimicrobial activity at $1 \mathrm{mg} / \mathrm{mL}$ (Coqueiro \& Di Piero, 2011), the HD chitosan in the present study significantly reduced bacteriosis at larger time intervals between treatment and inoculation. Furthermore, HD chitosan did not affect bacterial growth even at high concentration (3 


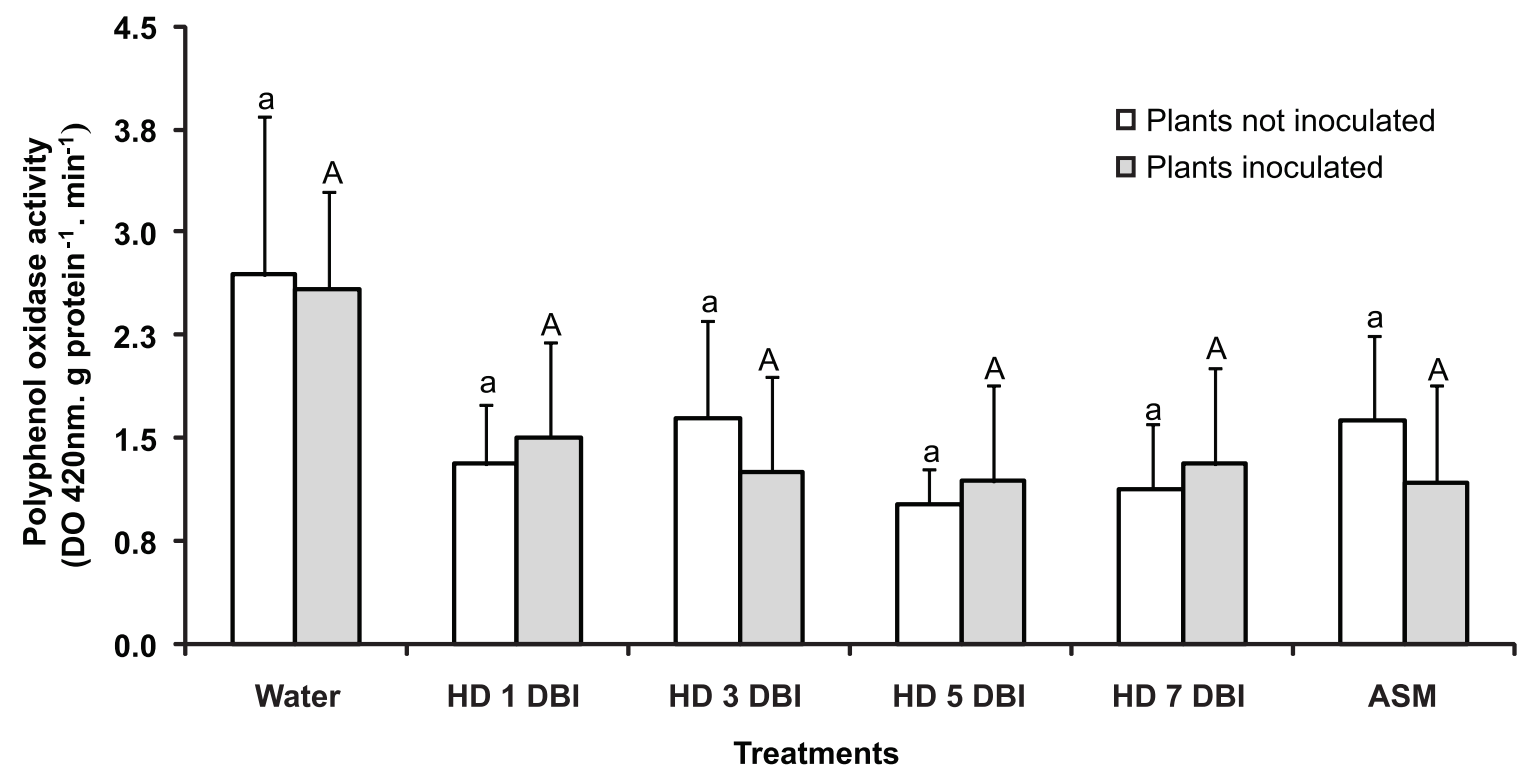

FIGURE 6 - Polyphenol oxidase activity on tomato leaves treated with high density (HD) chitosan (3.0 mg/mL), inoculated or not with Xanthomonas gardneri. Plants treated with distilled water and ASM ( $25 \mathrm{mg} / \mathrm{mL})$ served as negative and positive controls, respectively. HD 1 DBI, for example, means plants treated with HD at 1 day before inoculation. The leaf samples were collected immediately before inoculation (non-inoculated plants) and $48 \mathrm{~h}$ after (inoculated plants) to quantify polyphenol oxidase activity. Bars with the same letter do not differ statistically from one another according to Tukey's test at 5\% significance.

$\mathrm{mg} / \mathrm{mL}$ ), but increased the activity of peroxidases in plants, indicating that it acted as an inducer of resistance.

\section{ACKNOWLEDGEMENTS}

Our thanks to Coordenação de Aperfeiçoamento de Pessoal de Nível Superior - CAPES and Conselho Nacional de Desenvolvimento Científico e Tecnológico - CNPq for awarding fellowships.

\section{REFERENCES}

Alvarenga ES, Oliveira CP, Bellato CR (2010) An approach to understanding the deacetylation degree of chitosan. Carbohydrate Polymers 80:1155-1160.

Berger LRR, Stamford TCM, Stamford NP (2011) Perspectivas para o uso da quitosana na agricultura. Revista Iberoamericana de Polímeros 12:195-215.

Boava LP, Kuhn OJ, Paschoalati SF, Di Piero RM, Furtado EL (2010) Atividade de quitinases e peroxidases em folhas de eucalipto em diferentes estágios de desenvolvimento após tratamento com acibenzolar-S-metil (ASM) e inoculação com Puccinia psidii. Tropical Plant Pathology 35:124-128.

Bradford MM (1976) A rapid and sensitive method for the quantitation of microgram quantities of protein utilizing the principle of protein-dye binding. Analytical Biochemistry 72:248254.

Chung YC, Yeh JY, Tsai CF (2011) Antibacterial characteristics and activity of water-soluble chitosan derivates prepared by the
Maillard reaction. Molecules 16:8504-8514.

Cluzet S, Torregrosa C, Jacquet C, Lafitte C, Fournier J, Mercier L, Salamagne S, Briand X, Esquerré-Tugayé MT, Dumas B (2004) Gene expression profiling and protection of Medicago truncatula against a fungal infection in response to an elicitor from green algae Ulva spp. Plant, Cell and Environment 27:917-928.

Coqueiro DS, Di Piero RM (2011) Antibiotic activity against Xanthomonas gardneri and protection of tomato plants by chitosan. Journal of Plant Pathology 93:337-344.

Di Piero RM, Garda MV (2008) Quitosana reduz a severidade da antracnose e aumenta a atividade de glucanase em feijoeirocomum. Pesquisa Agropecuária Brasileira 43:1121-1128.

Duangmal K, Apenten RKO (1999) A comparative study of polyphenoloxidases from taro (Colocasia esculenta) and potato (Solanum tuberosum var Romano). Food Chemistry 64:351-359.

Falcón A, Cabrera JC, Costales D, Ramírez MA, Cabrera G, Toledo V, Martínez-Téllez MA (2008) The effect of size and acetylation degree of chitosan derivatives on tobacco plant protection against Phytophthora parasitica nicotianae. World Journal of Microbiology \& Biotechnology 24:103-112.

Hammershmidt R, Nuckles EM, Kuc J (1982) Association of enhanced peroxidase activity with induced systemic resistance of cucumber to Colletotrichum lagenarium. Physiological Plant Pathology 20:73-82.

IBGE (2012) Levantamento Sistemático da Produção Agrícola. Available at: www.sidra.ibge.gov.br/bda/pesquisas. Accessed on October 5, 2012.

Janisiewicz WJ (1996) Ecological diversity, niche overlap, and coexistance of antagonist used in developing mixtures for 
ciocontrol of postharvest diseases of apples. Phytopathology $86: 473-479$.

Kong M, Chen XG, Xing K, Park HJ (2010) Antimicrobial properties of chitosan and mode of action: a state of the art review. International Journal of Food Microbiology 144:51-63.

Loubaud M, van Doorm WG (2004) Wound-induced and bacteriainduced xylem blockages in roses, Astilbe and Viburnum. Postharvest Biology and Technology 32:281-288.

Luiz C, Felipini RB, Costa MEB, Di Piero RM (2012) Polysaccharides from Aloe barbadensis reduce the severity of bacterial spot and actívate disease-related proteins in tomato. Journal of Plant Pathology 94:387-393.

Mandal S, Mitra A, Mallick N (2009) Time course study on accumulation of cell wall-bound phenolics and activities of defense enzymes in tomato roots in relation to Fusarium wilt. World Journal of Microbiology \& Biotechnology 25:795-802.

Mello SC, Takatsu A, Lopes CA (1997) Escala diagramática para avaliação da mancha-bacteriana do tomateiro. Fitopatologia Brasileira 22:447-448.

Reuck K, Sivakumar D, Korsten L (2009) Effect of integrated application of chitosan coating and modified atmosphere packaging on overall quality retention in litchi cultivars. Journal of the Science of Food and Agriculture 89:915-920.

Roberts GAF (1992) Chitin Chemistry. London, UK. McMillan.

Sukul P, Spiteller M (2000) Metalaxyl: persistence, degradation, metabolism, and analytical methods. Reviews of Environmental Contamination \& Toxicology 164:1-26.

Sivakumar D, Sultanbawa Y, Ranasingh N, Kumara P, Wijesundera RLC (2005) Effect of the combined application of chitosan and carbonate salts on the incidence of anthracnose and on the quality of papaya during storage. Journal of Horticultural Science \& Biotechnology 80:447-452.

Tan H, Ma R, Lin C, Li Z, Tang T (2013) Quaternized chitosan as an antimicrobial agent: antimicrobial activity, mechanism of action and biomedical applications in orthopedics. International Journal of Molecular Sciences 14:1854-1869.

Usataya AS, Merenyuk GV, Katruk EA (1993) Biological activity of vineyard soils under de application of fungicides. Buletinul Academiei de Stiinte a Republicii Moldova. Stiinte Biologie Chimiee 6:40-42.

van Loon LC, van Strien EA (1999) The families of pathogenesisrelated proteins, their activities, and comparative analysis of PR-1 type proteins. Physiological and Molecular Plant Pathology 55:8597.

van Doorn WG, Vaslier N (2002) Wounding-induced xylem occlusion in stems of cut chrysanthemum flowers: roles of peroxidase and cathecol oxidase. Postharvest Biology and Technology 26:275-284.

Vaughn KC, Lax AR, Duke SO (1988) Polyphenol oxidase: the chloroplast oxidase with no established function. Physiologia Plantarum 72:659-665.

TPP-2014-0059

Submitted: 23 April 2014

Revisions requested: 26 May 2014

Accepted: 4 August 2014

Section Editor: Bernardo A. Halfeld-Vieira 